\title{
THE PREGNANCY RATE AFTER INTRAUTERINE INSEMINATION USING SEMEN WITH DIFFERENT LEUCOCYTES CONCENTRATION PREPARED BY SWIM-UP METHOD
}

\author{
HERMAWAN, G.A. ${ }^{*}{ }^{*}$ KUSWATININGSIH, D.N. ${ }^{1}$, PANGAYOMAN, J.T. ${ }^{1}$, \\ WIDYASTUTI, R. ${ }^{2}$ and BOEDIONO, A. ${ }^{3}$ \\ ${ }^{1}$ Morula IVF Melinda Bandung, Jalan Dr Cipto No 1 Bandung, Indonesia \\ ${ }^{2}$ Laboratory of Animal Reproduction and Artificial Insemination, \\ Departement of Animal Production, Animal Husbandry Faculty, \\ Universitas Padjadjaran, Jl. Raya Bandung Sumedang Km.21 Jatinangor Sumedang, \\ West Java 45363, Indonesia \\ ${ }^{3}$ Laboratory of Embriology, Departement of Anatomy, Physiology, and Pharmacology, \\ Faculty of Veterinary Medicine, IPB University, Jl. Agatis Dramaga Bogor, \\ West Java 16680, Indonesia \\ *E-mail:drh.geandri@gmail.com
}

Accepted 1 May 2020, Published online 6 July 2020

Infertility is a failure in condition of a couple to achieve pregnancy with regular intercourse without contraception for a year (Ventakesh et al., 2009). Leucocytospermia is one of the most common causes of male infertility. Leucocytes in semen represent the predominant source of Reactive Oxygen Species (ROS) both in seminal plasma and in sperm suspensions (Henkel, 2011). This preliminary study was aimed to evaluate the contribution of different leucocyte concentration in the sperm recovery rate after sperm preparation followed by Intra Uterine Insemination (IUI).

Semen samples were obtained from 49 male partners of couples undergoing an insemination. Semen collection and semen analysis was performed according to WHO 2010 guidelines and divided into four groups according to seminal leukocytes (PMNL) concentration: $A=>0$ to $\leq 1 \times 10(6) / \mathrm{mL}$; $\mathrm{B}=>1$ to $\leq 2 \times 10(6) / \mathrm{mL} ; \mathrm{C}=>2$ to $\leq 3 \times 10(6) / \mathrm{mL}$; and $\mathrm{D}=>3 \times 10(6) / \mathrm{mL}$. Semen samples prepared using Swim-up and were scheduled for IUI to be inseminated into patients. A pregnancy test was performed 14 days after insemination.

The results showed that group $\mathrm{C}$ obtained the highest sperm motility in semen samples before preparation and were statistically significant compared with the other groups $(\mathrm{p}<0.05)$ (Table 1$)$. It suggested that the level of ROS produced within group $\mathrm{C}$ was at an optimum level to support the

* To whom correspondence should be addressed. sperm for maturation and also increased sperm motility. The previous research reported that the optimum ROS level is crucial for cell regulation and sperm motility during maturation and capacitation (Ford, 2004).

Interestingly, the highest sperm concentration pre-preparation was obtained from group $\mathrm{D}$, but the total harvested sperm was obtained from group C (Table 2). The low harvested sperm concentration in group D may have a strong correlation with the high number of leucocytes. As a consequence,

Table 1. Sperm motility in pre-preparation and postpreparation based on the concentration of leukocytes

\begin{tabular}{|c|c|c|}
\hline \multirow{2}{*}{ Group } & \multirow{2}{*}{$\mathrm{n}$} & Subset for alpha $=0.05$ \\
\hline & & Pre-preparation motility (\%) \\
\hline$A$ & 16 & $39.4^{a}$ \\
\hline $\mathrm{B}$ & 14 & $41.5^{b}$ \\
\hline $\mathrm{C}$ & 11 & $47.36^{c}$ \\
\hline $\mathrm{D}$ & 8 & $46.75^{d}$ \\
\hline \multirow{2}{*}{ Group } & \multirow{2}{*}{$\mathrm{n}$} & Subset for alpha $=0.05$ \\
\hline & & Post-preparation motility (\%) \\
\hline$A$ & 16 & $92.8^{a}$ \\
\hline $\mathrm{B}$ & 14 & $90.4^{b}$ \\
\hline $\mathrm{C}$ & 11 & $91.91^{\mathrm{c}}$ \\
\hline $\mathrm{D}$ & 8 & $93.88^{d}$ \\
\hline
\end{tabular}

The data is expressed as average. Different superscript letters in the same column indicate a statistically significant difference $(P<0.05)$. 
Table 2. The sperm concentration pre-preparation and post-preparation, total sperm inseminated and pregnancy rate after IUI

\begin{tabular}{|c|c|c|}
\hline \multirow{2}{*}{ Group } & \multirow{2}{*}{$\mathrm{n}$} & Subset for alpha $=0.05$ \\
\hline & & average of ejaculate sperm (millions) \\
\hline A & 16 & 52.25 \\
\hline B & 14 & 55.72 \\
\hline C & 11 & 48.18 \\
\hline D & 8 & 72.62 \\
\hline \multirow{2}{*}{ Group } & \multirow{2}{*}{$\mathrm{n}$} & Subset for alpha $=0.05$ \\
\hline & & total harvested sperm (millions) \\
\hline A & 16 & 10.18 \\
\hline B & 14 & 10.22 \\
\hline C & 11 & 13.88 \\
\hline $\mathrm{D}$ & 8 & 9.94 \\
\hline \multirow{2}{*}{ Group } & \multirow{2}{*}{$\mathrm{n}$} & Subset for alpha $=0.05$ \\
\hline & & motile sperm inseminated (millions) \\
\hline A & 16 & 2.79 \\
\hline B & 14 & 2.93 \\
\hline C & 11 & 3.19 \\
\hline $\mathrm{D}$ & 8 & 2.45 \\
\hline \multirow{2}{*}{ Group } & \multirow{2}{*}{$\mathrm{n}$} & Subset for alpha $=0.05$ \\
\hline & & pregnancy rate (\%) \\
\hline A & 16 & 0.06 \\
\hline B & 14 & 0.07 \\
\hline C & 11 & 0.18 \\
\hline D & 8 & 0.13 \\
\hline
\end{tabular}

Data is expressed as average.

the ROS level within group D may be increased, so induced the imbalance between ROS and antioxidant concentration. A previous study found that ROS induced damage in various biomolecules such as lipids, amino acids, carbohydrates, protein and DNA, which adversely affected the sperm function (Ventakesh et al., 2009).

Based on the results, the highest pregnancy rate was obtained from group $\mathrm{C}$ although not significant compared with other groups. It was believed that the level ROS in group $\mathrm{C}$ is optimum for activation of tyrosine phosphorylation associated with capacitation for regular fertilization. The optimum concentration of ROS involved in diverse physiological functions of sperm, including capacitation, acrosome reaction, and binding to the zona pellucida (Chen et al., 2013). However, it has been proven that the ROS has negatively impacted the premature acrosome reaction that correlates to the inability of rat epididymal sperm in penetrating the zona-intact of the oocyte (Widyastuti et al., 2018).

\section{ACKNOWLEDGMENT}

The authors would like to thank Morula IVF Melinda Bandung, for supporting this research.

\section{REFERENCES}

Chen, S., Allam, J., Duan, Y. \& Haidl, G. 2013. Infuence of reactive oxygen species on human sperm functions and fertilizing capacity including therapeutical approach. Reproductive Medicine, 288: 191-199.

Ford, W.C.L. 2004. Regulation of sperm function by reactive oxygen species J. Human Reproduction Update, 10(5): 387-399.

Henkel, R.R. 2011. Review: Leukocytes and oxidative stress: dilemma for sperm function and male fertility. Asian Journal of Andrology, 13(1): 43-52.

Ventakesh, S., Riyyaz, A.M., Shamsi, M.B., Kumar, R., Gupta, N.P., Mittal, S. \& Malhotra, Nand. 2009. Clinical significance of reactive oxygen species in semen of infertile indian men. $J$. Andrologia, 41(4): 251-256.

Widyastuti, R., Pangayoman, J., Riyanti, A., Lubis, A. \& Syamsumarno, M.R.A.A. 2018. Pregnancy rate after intrauterine insemination with the presence or absence of leukocytospermia in sperms prepared using density gradient method. Int J Health Sci, 6(2): 63-6. 